\title{
The Existence of Women in the Batak Angkola Family in North Padang Lawas
}

\author{
Syukur Kholil $^{1}$, Iskandar Zulkarnain ${ }^{2}$, Irma Yusriani Simamora ${ }^{3}$ \\ 1,2,3 Universitas Islam Negeri Sumatera Utara, Indonesia \\ irmayusriani75@gmail.com
}

\begin{abstract}
In fact, women who are born into the world have the same rights as men. However, the reality shows that women who live and settle in North Padang Lawas have different rights and treatment from men. Such unequal treatment is based on existing customs and has been entrenched for a long time in people's daily lives. This paper aims to determine the existence of women in the Batak Angkola family in North Padang Lawas from the perspective of the customs prevailing in North Padang Lawas. The conclusion is that the values, norms and culture that exist in the Batak Angkola community in North Padang Lawas have unconsciously created symbolic violence against women even though they feel that what they experience is not a form of violence. However, it is natural and also a form of devotion and a form of affection for the family. There have been several changes and shifts in the values and cultural norms that exist in the Batak Angkola community of Padang Lawas Utara. The changes and shifts are continuous, some are due to the demands of the times, as well as the higher level of education, experience and acculturation that exist in the Angkola Batak community. Meanwhile, Islam views humans as creatures who have the same basic rights regardless of gender.
\end{abstract}

Keywords

existence; women, batak angkoda; North Padang Lawas

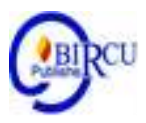

\section{Introduction}

The issues concerning women are still very interesting to study. This is because issues concerning women always indicate an impression of marginalization and intimidation for women's interests. The fact that is put forward is of course very interesting to explore, especially when connecting women with certain societal cultures, which generally always do not provide reasonable appreciation and are sometimes very inappropriate for women. Because in general, existing cultures always position women to be number two compared to men.

In this regard, it is interesting to point out, for example, the existence of women in the Angkola Batak community who adhere to a very strict patrilineal system in the kinship system. The existence of a daughter in the family is often seen as the second person in the family, even though in reality she is the first child in the family. Women are considered part of his father's group, only before he is married. When a woman in the Batak Angkola family is married, automatically she is no longer entitled to live in her father's house, because she is considered to have been sold to the male family, and this is reinforced by the words "boli" (bride price) which must be paid by the male to the female's parents. The words boli are more often interpreted by people with the word "buy" so that the connotation is that a man buys a woman with the dowry he gives. This of course has made 
a girl like an item, which means that after marriage she has to leave her parents' house and follow her husband's family. And automatically the rights of women as children will be lost. She will be included in her husband's kinship unit but remains limited in power.

Differences in the existence of girls are not only visible in daily treatment but also in the family system of the Batak community. This is reinforced by the philosophy of life adopted by this society, namely: first: "reveal marmara anak, marmara boru". Second: "the child is pumped up in the boru ambit." Third: "Anak Hamatean Boru Hangoluan". Fourth: "Anak Do Sinuan shoots by combing fur, Boru Do Sinuan Boyu". The Batak philosophy of life about women clearly shows the impression of differentiating boys from girls. Coupled with the statement of the parents when the daughter will leave the house of her parents on the day of the wedding "with this marriage, the rights of the parents to the daughter have been released, because women have totally entered into the kinship of her husband. From several philosophies of life that have become role models for the Batak Angkola community, it can be seen that the existence of girls in the Angkola Batak family is marginalized.

The difference in treatment of girls is not only in the system structure but also in everyday life. Starting from the welcome at birth, the treatment and facilities obtained from the family, the right to education, the right to express opinions, the marriage party, the inheritance rights (according to the Batak people, widows and daughters are not entitled to inherit from their husbands and parents). Although there have been many changes in inheritance.

The form of women's opposition to men's power is inseparable from an unjust patriarchal system. Society with a patriarchal culture from the beginning assumed that men were stronger than women in personal, family, community and state matters. Until now, patriarchal culture is still lasting in the fabric of Indonesian society. This culture can be found in various aspects and scope, such as economics, education, law, and politics. (Wayan et al, 2020)

There are so many unique things here that are interesting to research, as far as this research is carried out in the context of the Batak Angkola community in North Padang Lawas, which is generally influenced by Batak culture as well as Islamic teachings. Because in their daily lives most of them are also devout Muslims and also have had the title of Hajj, but in their daily affairs they still seem unable to balance the teachings of Islam and customs. They still seem to tend to side with adat to become their role model in life. So that the values of Islamic teachings are only limited to routine worship, not a way of live.

It is undeniable that people who are more advanced in education, economy and also live in urban areas, have given reasonable efforts to girls, especially in providing education. However, cultural bias still influences the existence of women in the Batak Angkola family in Padang Lawas Utara. With the above facts become the main reason for researchers to research "The Existence of Women in Batak Angkola Families in North Padang Lawas" 


\section{Review of Literatures}

\section{The Existence of Girls in Batak Angkola Families in North Padang Lawas}

\section{a. The Meaning of Existence and Symbolic Violence}

Ethnicity as one that sustains a sense of primordialism is often interpreted as a social group in a social or cultural system that has a certain meaning or position because of heredity, customs, religion, language, and so on. Members of an ethnic group have a common history (ancestry), language, value system, customs, and traditions. Overall, the ethnic group takes an important position in the social interaction of the intermingling process in all ethnic groups of indigenous peoples in the social community. (Angkat et al, 2019)

Existence in the Big Indonesian Dictionary is defined as existence. The existence here is how the Angkola Batak customs and culture view the existence of women in the family. If we take a quick look, we will see that in the Batak Angkola family, women tend to experience violence, be it violence in the family or in society. This violence is actually not something new, violence is often carried out together and without realizing it is violence. The violence referred to here is symbolic in nature, whether it is through words, deeds or symbols that apply to society. Whereas violence in the Indonesian state is a form of criminal act, as regulated in the Criminal Code.

In reality, it is very difficult to measure precisely the extent of violence against women, thus, there are many studies that report a very broad type of violence, namely domestic violence, particularly violence perpetrated by husbands or partners. ${ }^{1}$ The division of social roles in which women occupy the domestic sphere, while men are the political sphere, can cause inequality and inequality. In addition, patriarchal culture in society, often inhibits society, often prevents women from being in society.

Violence against women has the characteristics of action, including:

a. Can be physical or non-physical (psiskis)

b. Can be done actively or passively (not doing)

c. Wanted / not interested by the perpetrator

d. There are consequences / possible consequences that are detrimental to the victim (physical or psychological), which the victim does not want.

The shift in the role of women that penetrates into the public sphere often faces challenges and obstacles. One manifestation of this injustice is the appearance of "competition", especially if women are more successful in the profession in the public sphere, this sense of competition can lead to disharmony in the household, especially for husbands who feel unable to achieve a career resulting in a break in the relationship between husband and wife. This situation can be seen from the reality in society. However, in order to maintain a good name, women prefer to remain silent. Responding to what happens in the household and violence against women, the United Nations (UN) needs to provide a definition of the definition of violence against women and children.

Article 2 of the United Nations Declaration on the Elimination of Violence against Women states that: "Violence against women is any act based on sex differences that results or may result in suffering and suffering women physically, sexually or psychologically, including threats of certain actions, coercion or arbitrary deprivation of liberty authority either that occurs in public or in private life". 
In line with the development of the problem of violence, on 22 September 2004 regarding the elimination of violence that occurred within the household sphere was no longer processed based on the regulations listed in the Criminal Code, but was handled based on this special law. With the hope that justice seekers will feel more cared for and protected by the new law.

Therefore, it can be understood that violence against women can be physical or nonphysical, in the language of symbolic violence researchers. Then the researcher will discuss in more detail about symbolic violence, which is as follows:

\section{b. Definition of Symbolic Violence}

In the Big Indonesian Dictionary, violence means coercion, while the symbolsmeans symbol. In terms of language it is understood that violence is coercion through symbols, meaning symbolic violence is coercion that is abstract in nature, only in the form of cultural symbols or values that violence occurs unconsciously, but violence has occurred. Symbolic violence is present because of the efforts of the dominating party to corner the dominated party, symbolic violence mostly occurs against women because the position of women in society is always placed second after men. Furthermore, the dominated party simply believes without questioning what has happened to them, and they simply accept what has happened to them.

As time goes by, symbolic violence begins to be felt by women, women begin to be critical of what has not been felt so far. In the end, what is abstract turns out that from a gender perspective, it is violence against women. Violence against women can be seen from

two analyzes, the first is radical analysis, which is a violent manifestation of congenital male sexual aggressiveness. Second, violence on structural issues that are systematic based on sex differences and sexual division of labor.

With the times and the increasing understanding and knowledge of women about social inequalities, the meaning of violence has expanded its meaning, which includes attacks or information on one's physical and psychological mental integrity.

Structural theory that is seen as accommodating women's awareness of violence against women can be seen in the $1994 \mathrm{UN}$ declaration, asserting that violence against women is violence perpetrated on the basis of sex differences, which results in or can harm women, both physically, psychologically, and sexually, including the threat of such acts, coercion or arbitrary deprivation of liberty, whether occurring in public or private life.

Thus, violence against women can be physical, clearly discrediting women, and some are symbolic, abstract in nature, not realizing that violence exists, but in practice violence occurs against women.

Gender is linguistically derived from English, gender means gender. Meanwhile, the term gender according to Webster's New World Dictionary, is defined as the visible difference between men and women in terms of values and behavior. In the Women's Studies Encyclopedia it is explained that gender is a cultural concept that seeks to contain differences in terms of roles, behavior, mentality and emotional characteristics between men and women that develop in society." 


\section{c. Forms of Violence}

\section{Sexual violence}

Sexusal violence is violence in which sexual will is forced and results in violence by the perpetrator and the victim unwilling. Like rape, rape occurs because there is no desire from women, women are forced to do it. Sexual violence includes all acts of an exploitative, discriminatory, intimidating and criminal nature, but is not accompanied by sexual will, which harms women, both physically and psychologically.

2. Sexual harassment and sexual assault

Sexual harassment can be in the form of rape, sexual harassment can be defined as the level of mild, moderate. There is sexual harassment as a minor rape, whereas sexual assault is categorized as severe intense sexual violence.

3. Domestic Violence and Public Violence

Domestic violence in principle consists of three types, namely: intimate violence, private violence, family violence. Domestic violence is known as KDRT, in BAN 1 Art. 1 Law 232004 Domestic violence is any act against a woman, which results in physical or psychological suffering or suffering. whereas public violence includes all forms of sexual harassment and sexual assaults which are committed in public places.

Apart from the three forms of violence mentioned above, there are forms of violence according to Law Number 23 of 2004, listed in article 6, article 7, article 8, article 9, namely:

1. Physical violence, namely actions that cause pain, fall ill or become seriously injured (article 6 of law number 23 of 2004).

2. Physical violence, namely actions that cause fear, loss of self-confidence, loss of ability to act, feeling helpless or acting, feeling helpless or severe psychological suffering in a person (article 7 of law number 23 of 2004).

3. Sexual violence, namely forced sexual intercourse with those who live within the scope of the household. Apart from that, it also means that one person in the household is forced to have sexual relations. Apart from that, it also means forcing sexual relations between one person within the scope of his household with another for commercial or specific purposes (article 8 of law number 23 of 2004).

4. Domestic neglect is also included in the definition of violence, because every person is prohibited from neglecting someone within the scope of the household, even though according to the law that applies to him or because of an agreement or agreement he is obliged to provide livelihood, care or maintenance to that person. (Article 9 of law number 23 of 2004).

Various kinds of violence occur in the family and in society, wherever the presence of women always occurs violence, be it physical or non-physical violence, or real or symbolic violence.

\section{Results and Discussion}

\subsection{Cultural Values That Regulate the Relations of Men and Women in Batak} Angkola Community in Padang Lawas Utara

\section{a. Successor to the Family}

In the Angkola Batak family, which strongly adheres to the patriarchal culture, it is hoped that the birth of a son in the family as the successor of the family Which is the son who is the foundation of the family, because the boy can carry on his descendants and also clans. So that if a family has not been blessed with a son, it is considered a family disgrace, therefore parents do not hesitate to order their son to remarry, and that will be supported by 
the family, plus support from the community. This is especially so if the woman (wife) is no longer able to give birth. As long as the woman (wife) is still able to give birth, she will continue to do so even though she has given birth to eight or nine daughters until she gives birth to a boy. It's not something extraordinary, but it is what should be done in the family. Because in the view of the Angkola Batak community, if this is not done then the family's descendants will stop there,

In the family, be it a father, grandfather, or any other family, when a boy is born, they are proud to convey it to others. However, if a girl is born, they accept it as something normal, because the culture that has placed the position of girls is not as high as the status of boys. The position of girls in Batak society is always second, whether in daily treatment, family facilities, education, treatment in society, distribution of inheritance and so on. The smallest example, when a boy is born into the world, then the large Batak family will greet him with joy and various ceremonies, including: swinging, naming and others. It's different if a girl is born, There is rarely a welcoming ceremony such as welcoming a boy. Between boys and girls there are differences in the reception of a newborn child.

\section{b. Education for Boys and Girls}

In general, the Batak Angkola people are very aware of the importance of education, both men and women. At the basic education level, parents feel that every child is obliged to get an education. However, when entering higher education, there will be a striking difference between boys and girls, especially if the parents are less able to send all their children to school. So that parents often decide which boys are given the opportunity to go to school. Even though in reality, girls have more abilities and awareness of the importance of education. However, this will not be a consideration for parents in sending their children to school. because for them no matter how high school and career a girl will not be able to raise the dignity and status of the family because the girl will go to marry someone else. It is different with boys, who will later become the foundation of hope and who will also elevate the family's status and dignity if they succeed in education as well as career and economically. That is a consideration so that parents will desperately send their boys to school.

\section{c. Customs}

In terms of customs that exist in the Angkola Batak community, the position of women is always second, both in "siriaon sangape siluluton" (marriage and grief). Women are always complementary, for example if a man (husband) dies, then his wife who is left behind has no right to leave the family environment of the deceased husband. If she wants to get married, she has to get permission from the family of her late husband, not from her parents. In fact, it is not uncommon for her husband's family to find her soul mate either from family or other people, and more often than not, a wife is required to marry (younger sibling or brother) "kahanggi "From her late husband, even though" kahangginya "sometimes already has a wife. Or a wife who is left dead by her husband is obliged to marry her sister-in-law who is single and has been considered a child, because she lives with them, because of the necessity in custom, they are obliged to marry. Whereas in Islam a widow has the right to marry a man she wants and can represent her guardian other than her parents (guardian of the judge).

It is different if the wife who dies, without asking for the consent of the brother-inlaw (Bujing ni daganak), the family will immediately direct the husband to marry his brother-in-law to step down on the grounds for the sake of the children. This understanding is also supported by a myth circulating in the community: "If a wife dies and she leaves a 
younger sister who is not married, and the younger siblings bathe her brother's body in the legs, then it is a sign that he wants to replace his brother's position." Even though it is not certain that the younger brother (bujing) wants to marry his brother-in-law, he did this because he felt sorry for his brother who had died.

\section{d. Distribution of Inheritance}

The distribution of inheritance based on the appointment without any standard rules is a system that has long been in effect among the Angkola Batak community. This system is characterized by the absence of a definite share of the respective heirs, especially the share of girls. Usually girls will only get the share that boys deem no longer desirable. For example, the youngest son usually gets a house that is abandoned by his parents. Meanwhile, girls usually get the portion that has been designated by boys, either in the form of a plot of land or a house unit. The plot of land or one housing unit will be divided equally by the girls, regardless of how many girls there are.

\section{e. The Requirement for Women to Go To the In-Laws' House during Eid}

As humans, women are also children of their parents, and as children they expect to be with their parents during Eid. But this is not the case for the Angkola people. In the culture of the Angkola people, it is something that is taboo, a disgrace, even to the point that there is a sign that there is a problem if during Eid a married girl returns to her parents' house. Parents also tend to feel embarrassed if their daughter who is married but Eid at the parents' house.

Now, this situation has begun to shift, the community has begun to be able to accept and understand if a married woman is celebrating in her parents' house, especially this has been agreed upon by the husband and wife and even their respective parents, plus support from educational factors and social experience.

\section{f. Decisions in the Family}

In the family, there are often things that must be decided, starting from the name, the child's school, marriage partners and all matters related to the family, the man is always the decision maker. For example, choosing a name for the child, if the father or grandfather (Oppung Suhut) has a proposed name then that is prioritized even though the wife doesn't agree. Likewise with everything that has to do with family, always the reference is what is the husband's decision, and the wife does not feel there is a problem, and always tells her children "ask the father" and what the father's decision will apply. in the family.

\subsection{The Attitudes of Batak Angkola Women in North Padang Lawas in Accepting Cultural Values about the Relationship between Women and Men}

Score-The cultural values regarding the relationship between women and men that have existed in North Padang Lawas are generally accepted by the Batak Women of Padang Lawas Utara. According to them, the treatment they receive as described above is not a form of violence, but it is an obligation and dedication that is hereditary and a necessity for a woman. In fact, if the opposite happens, they feel it is something new and strange and violates prevailing customs.

However, due to several factors, including education, experience and healthIn terms of family welfare, the majority of women in North Padang Lawas can no longer accept this treatment. They consider it to be discriminatory treatment and injustice. 


\subsection{Shifting Cultural Norms Values in Relationships between Men and Women in Padang Lawas Utara}

Based on facts in the field, the cultural norms values the relationship between men and women in Padang Lawas Utara in general has undergone a shift and some have even undergone many changes.

The norm values that have undergone many changes are as follows:

1. Education for girls

Currently, more girls are continuing their education to a higher level than boys, this is because boys are more likely to be unable to finish school because of "scattered" than girls. Due to these circumstances, parents often direct girls to school while boys are directed to have a business, or at least they are equally encouraged to continue their education to the limit of their parents' ability. In other words, every child is given the freedom to choose, continue school or not. This has a positive impact on increasing opportunities for girls to get jobs, or even in important positions in government institutions.

2. Decisions in the family

The father as the head of the family has begun to want to have deliberations in deciding various problems, especially if it is a matchmaking issue, the father will always ask his wife's opinion and also from the children concerned In fact, it is not uncommon for a father to ask if his son has a candidate before the father submits the candidate he means. Even though every candidate submitted by the child will still be selected by the father, the decisions are made based on the results of deliberation. The situation as mentioned above does not yet apply as a whole to the Batak Angkola community in North Padang Lawas, depending on the education, social status, economy and also the experience of each.

3. Facilities for girls

Parents better understand the needs of their children regardless of their gender status, for example: many parents have provided equal facilities for boys and girls. If boys get facilities in the form of transportation facilities such as trains, for example, the girls are also not left behind. Although it cannot be denied that equal rights to facilities are not always meant to be the same and exactly. The differences remain. Not infrequently, nowadays girls receive more facilities from their parents.

4. Syria

The Angkola Batak community no longer differentiates between the parties for boys and girls. It all comes down to the ability of the woman's parents.

\subsection{The Existence of Women in Family and Society in Islamic Perspective}

Islamic teachings want people in their lives to be always happy and full of peace. Nevertheless, humans always encounter obstacles to achieve this goal, due to violations of human rights, even though various conceptions have been formulated to guarantee these basic freedoms. To achieve this happiness and peace, humans must return to the conception of the Koran. There are several conceptions of human rights, among them are:

\section{a. Right to Life, Liberty and Personal Security}

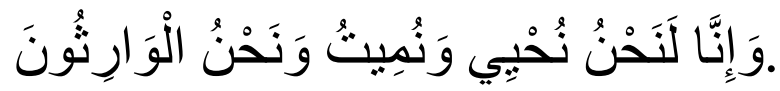

Meaning: "And it is really we who turn on and off, we (also) inherit". (Surah Alhijr: 35). 


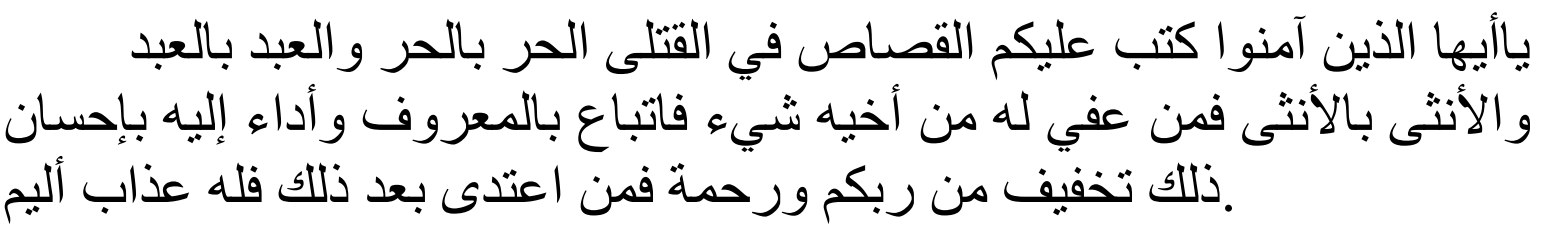

Meaning: "O you who believe! It is obligatory on you (carry out) qisoa with respect to the person who is being killed. Free person and free, slave and slave, let him follow him well, and pay him the diat (ransom) properly (too). Such is the loss and mercy of your Lord. Whoever goes beyond the limit after that, he will get a very painful punishment. (QS 2: 178).

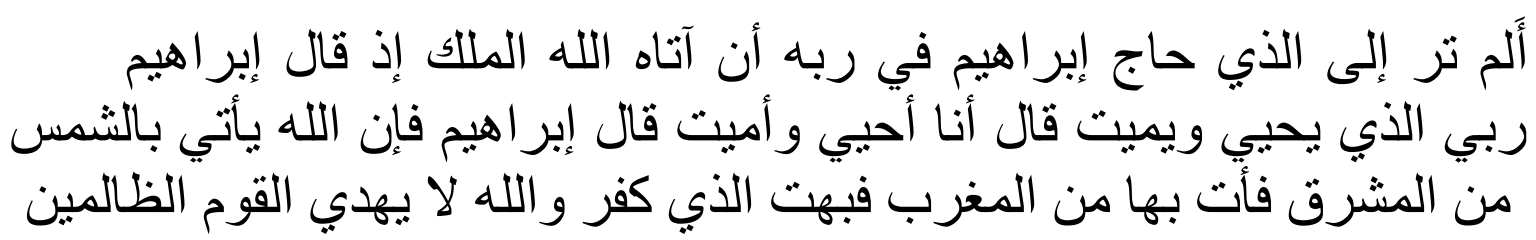

Meaning: "Do not you pay attention to people who argue about Abraham about his Lord, because Allah has given him the kingdom (power). When Ibrahim said, "I too can turn on and off." Ibrahim said, "Allah raises the sun from the East, so publish it from the West." Then the disbelievers are confused. Allah does not guide the wrongdoers. QS 2: 258).

من أجل ذلك كتبنا على بني إسر ائيل أنه من قتل نفسا بغير نفس أو فساد إنساد

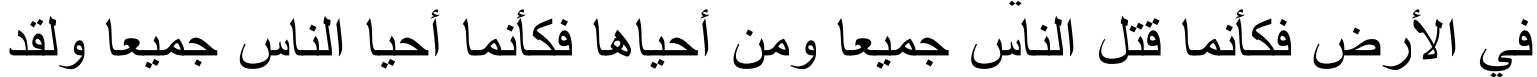

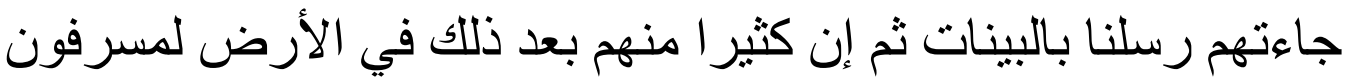

Meaning: "Therefore we stipulate (a law) for the Children of Israel, that whoever kills someone, not because that person killed other people, is as if he has killed all humans. Whoever maintains the life of a human being, it is as if for he has preserved the lives of all mankind. Indeed, our Apostle has come to them (with) clear information. But then many of them after that transgressed the bounds of the earth.

\section{b. Right of Opinion الَّنَ

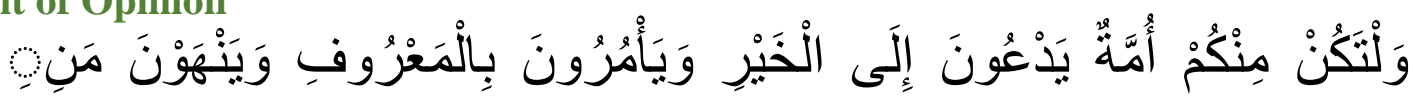

Meaning: "And let there be among you a group of people who call for virtue, command (do) what is correct, and prevent what is wrong, and they are the lucky ones". (QS 3: 104).

$$
\text { وَ الْقَلَمَ وَمَا بَنْطُرُون }
$$

Meaning: "Nun, By the Pen, and what they wrote". (QS 68: 1)

With the stroke of a pen, people can express their opinions, know the opinions of others, explore science, fight for their rights and so on. The scratches of the pen in expressing this opinion must always pay attention to social ethics and also not to harm others according to the principle of amar ma'ruf nahi munkar. 
c. Rights of Association and Association

$$
\text { فَجْهِعَ السَّحَرَةُ لِمِيقَاتِ يَوْمِ مَعْلُومٍ }
$$

Meaning: "Then gathered the magicians at the appointed time on the appointed day". (QS 26: 38).

\section{d. Right to Get a Job}

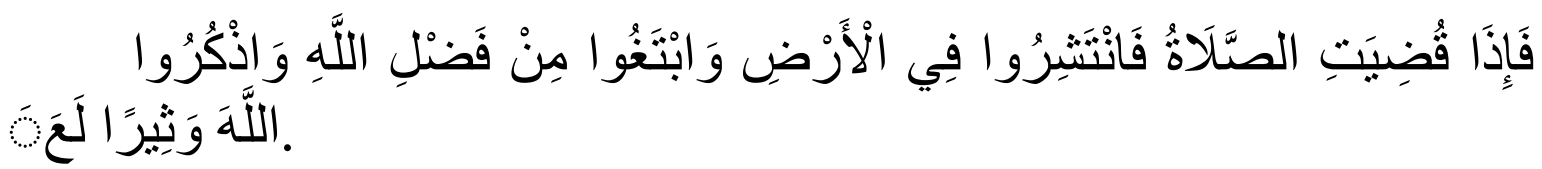

Meaning: "So when after the prayer is finished, you will be scattered on the earth, seek Allah's grace and remember Allah a lot so that you are lucky". (QS 63:10)

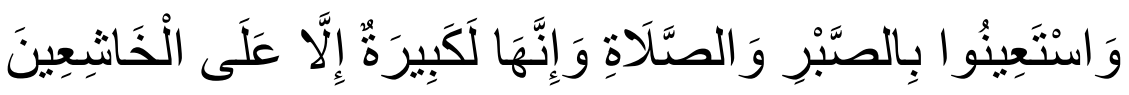

Meaning: "And ask for help (to Allah) patiently and pray. And prayer is really hard, except for people who are devoted '. (QS 2:45).

\section{e. Right to Education}

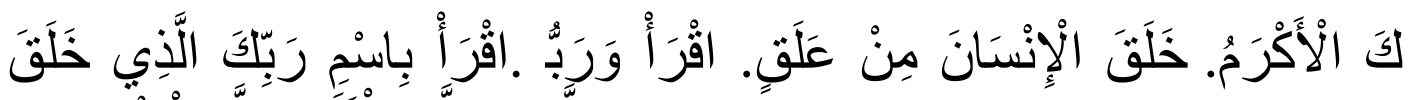

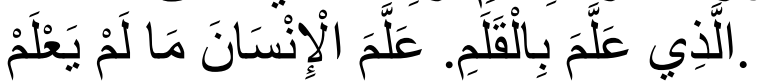

Meaning: "Read by saying the name of your god who created. He created man from a clot of blood. Read it, and it is your Lord who is most glorious. Who teaches man with a pen. And teach man what is not known ". (QS 96: 1-5).

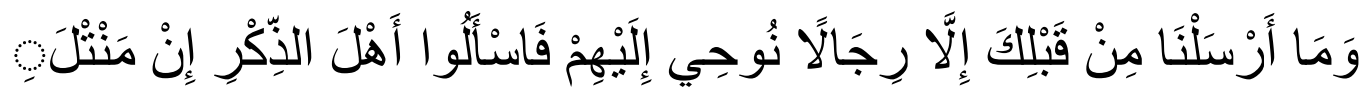

Meaning: "And we did not send before you (Muhammad), but men whom we gave revelations to them, so ask those who have knowledge if you don't know". (QS 16:43).

From the above verses of the Koran, it can be seen clearly and unequivocally that in essence humans have the same rights and obligations. Boys and girls have the same right to life, have the same opinion, have the same rights of association and association, have the right to get the same job, and have the same rights to education. The people of North Padang Lawas, as people who believe in Allah and His Messenger, should always be consistent in practicing the religious teachings outlined by Allah and His Messenger as stated in the Koran and Hadith. In fact, what distinguishes humans is only the level of submission to Allah and His Messenger. The higher the level of a person's piety, whether he is male or female, the higher his rank in the eyes of Allah and so in the eyes of humans. 


\section{Conclusion}

From the descriptions above it can be concluded as follows:

1. The values, norms and culture that exist in the Batak Angkola community in Padang Lawas Utara have unwittingly created symbolic violence.

2. The women of Batak Angkola in Padang Lawas Utara do not feel that what they experience is a form of violence. However, everything they experience is natural and also a form of devotion and a form of affection for the family.

3. There have been several changes and shifts in the values and cultural norms that exist in the Batak Angkola community of Padang Lawas Utara. Changes and shifts are continuous, some are due to the demands of the times, as well as higher levels of education, experience and acculturation that exist in the Angkola Batak community.

4. Islam views humans as creatures who have the same basic rights regardless of gender. They have the same rights to live, work, associate, express opinions, receive education and so on.

\section{References}

Angkat, M. et al. (2019). Construction of Religious Identity in Pakpak Culture Community in Dairi District. Budapest International Research and Critics Institute-Journal (BIRCI-Journal). P. 487-494.

Departemen Pendidikan Nasional, Kamus Besar Bahasa Indonesia, Jakarta: Balai Pustaka, 2007.

Fakih, Mansour, Analisis Gender dan Transformasi Sosial, Yokyakarta: Pustaka Pelajar, 1996.

Hadiati Soeroso, Moerti, Kekerasan Dalam Rumah Tangga, Jakarta: Sinar Grafika, 2010.

Hasil Musyawarah Parsadaan Marga Harahap Dohot Anak Borunya, HORJA (Adat Istiadat Dalihan Na Tolu), Bandung: P.T Grafitri 1993.

Hamidy, Basyral, Siala Sampagul, Pemerintah Kota Padang Sidempuan: Pustaka, 2004.

Indra, Hasbi, Iskandar Ahza, Husnani, Potret Wanita Shalehah, Yogyakarta: Graha Ilmu, 2007.

Koentjaraningrat, Manusia dan Kebudayaan di Indonesia, Jakarta: Djambatan, 1993.

Muliadi, Perlindungan Wanita Terhadap Tindakan Kekerasan, Yokyakarta: Kansius, 1997.

Pusat kajian Wanita dan gender, UI dan Yayasan obor Indonesia, Hak AzasiPerempuan (Instrumen Hukum Untuk Mewujudkan Keadilan Gender), Jakarta, 2007.

Puta, Dalizar, Hak Asasi Manusia Menurut Alquran, Jakarta: Husna Zikra, 1995.

Roger M. Keesing Samuel Gunawan, Antropologi Budaya Suatu Perspektif Kontempo, Jakarta: Erlangga, 1992.

Sumbulah, Umi, Spectrum Gender (Kilasan Inklusi Gender di Perguruan Tinggi), Malang: UIN - Malang Press, 2008.

Vergouwen, J.C, Masyarakat dan Hukum Adat Batak Toba, Jakarta: LkiS, 1986.

Wayan, K and Nyoman, S. (2020). Women and Cultural Patriarchy in Politics. Budapest International Research and Critics Institute-Journal (BIRCI-Journal). P. 2158-2164.

Winansih, Varia, Kajian Pengembangan Model Pusat Pelayanan Terpadu Pemberdayaan Perempuan (P2TP2) di Sumatera Utara, 2005, 32. 